\title{
Problems in the Construction of the Characteristic Development of College Specialties of Local Universities
}

\author{
Wang Qiuyuan \\ Professor in School of Foreign Language, Baicheng Normal University
}

\begin{abstract}
The characteristic development of college specialties is a basic requirement for the teaching quality of universities; meanwhile, it determines the survival and development abilities of the university in the market. This paper explores the construction of the characteristic development of college specialties of undergraduates, explains the constructional demands of the characteristic development of college specialties of local universities and emphasizes that the characteristic development of college specialties needs to create professional values with characteristics and improve the professional's cultivation standard.

Key words: Local universities; The characteristic development of college specialties; Construction; Program
\end{abstract}

\section{Introduction}

The cultivation of professionals is the primary responsibility of universities, which needs strong disciplinary and professional abilities as well as multiple elements, such as high-quality teaching resources, teaching researches, teaching abilities and professional training base, etc. In order to realize the construction of the characteristic development of college specialties of undergraduate in local universities, universities need to combine disciplinary and professional abilities, improve cultivation of talents and put the effectiveness of the construction of the characteristic development of college specialties to the priority and strengthen the construction of universities themselves so as to promote characteristic specialties enter the first-rate major ranks in the country. This paper takes English majors in universities as the direction and makes a detailed analysis on the problems in the 
construction of the characteristic development of college specialties.

\section{Cognition of the construction of the characteristic development of college specialties and characteristic specialty}

Specialty refers to unique styles possessed by an object that are different from other things, and it is mainly determined by the object's survival and development environment. This is the object's unique property. "Specialty" of university undergraduate major means the unique characteristics of a major during the long-term development process of education. These characteristics might be represented in professional knowledge or professional teaching. The properties of the characteristic development of college specialties must be recognized by other universities so that it can obtain comprehensive praises from the society.

Construction of the characteristic development of college specialties is a conscious characteristic-building project. It has strong subjective consciousness. Through the extraction and promotion of the historical experiences of the characteristic development of college specialties, specific construction is conducted so as to complete the professional system. The main goal is to promote the more distinct and more unique properties of the characteristic development of college specialties in the circulated development process so that the major can occupy an advantageous status in the fierce demands of social market.

\section{Demands for the construction of the characteristic development of college specialties in economic market}

As a core part in teaching system, curriculum system has been through different development stages in educational development. If English major is to obtain characteristic development, it must treats the cultivation of talents as the entry point of characteristic innovative development and truly implement the teaching philosophy of specialized knowledge talents cultivation through specialized courses, specialized knowledge and skills, training base and internship and employment posts and so on.

Under the current social development background, foreign language is regarded as a life skill; meanwhile, it is a carrier of language. When this skill is combined with a carrier, it can be called a major. Therefore, when faced with demands for market talents, universities' construction of the characteristic development of English major needs to walk towards the talent market situation of "skill + carrier" to determine the value orientation of the training of professional English talents. Under the premise of propelling the characteristic development of college specialties, the construction of the characteristic development of English major must combine the history and faculty of local universities, aim at social requirements of the area and the university's orientation, start from realities and make better choices. According to investigations, English 
majors in some universities can rarely get attention from the universities mainly because the orientation of talent-cultivation does not conform to the university themselves. Therefore, in the current catalogue of Chinese universities, the basic knowledge of many majors which involve the combination of multiple majors is broad, and cannot reach comprehensiveness in major construction; they can only treat the advantageous direction of the original major as objects of key construction so as to promote the long conservation of the major's features in the survival and development of the universities.

\section{Other problems in the characteristic development of college specialties of local universities}

Characteristic development of any discipline must be established on the historical course of the major's development and summarize specialized features of the school's orientation sufficiently according to the experiences and features accumulated in the development process. Then, it should improve features of the major and win the society's recognition though teaching objectives, teachers' qualifications, specialized course systems and teaching conditions and so on.

English major in universities is an important major that adapts to the development of local universities. To strengthen the construction of the characteristic development of English can lay basis for the competitions among local universities. Under the background of Chinese social culture, English is the demand for international communication as a foreign language discipline. This is also one of the reasons for universities to construct English professional teaching. As an instrumental discipline, firstly, English teaching has strong practicability. When universities put the cultivation of English abilities at the priority of English teaching, students can not only grasp English knowledge proficiently, but also can apply English techniques widely in real life. Then, English is a humanity discipline, and universities must cultivate students' comprehensive humanity qualities so that they can have some quality basis when applying English knowledge in social life. When universities are constructing the characteristic development of English major, they should combine the instrumental property of English teaching with humanity, improve the quality of English teaching and highlight the specialty of English major.

Specialty characteristics are extracted from the historical development of the specialty, and the ultimate goal is to train professionals needed by the society. Teaching activities are the major form of characteristic development. No matter it is educational goal or curriculum system or characteristics of teaching conditions and cultivation quality, it is teachers that implement major influence factors of teaching activities. Therefore, in characteristic development, the construction of the teaching staff in universities are the most crucial key construction.

In English majors of universities, the construction of a top English teacher team is a key link for universities to cultivate English professionals as well as an inevitable requirement for universities' development[1]. Firstly, English teachers' 
teaching standard must be improved, and teachers are required to reach teaching effect maximization during teaching process by means of the knowledge and social experiences they learned in their entire life; while the improvement of teachers' teaching standard is mainly represented in two aspects, i.e., teachers' class teaching and theory teaching. English classes involve both Eastern and Western cultural differences as well as teaching resources. Teachers' optimization of the preparation of English classes can solve teachers' deviation of English understanding in classes as well as habitual wrong pronunciations. In class teachings, teachers should also adhere to correct teaching philosophy, value the interaction between teachers and students, guide students to have innovative learning of English so as to guarantee the effects of English class teaching and improve teachers' teaching practical experiences and professional qualities. In addition, teachers' scientific research abilities should also be cultivated. Scientific research abilities are the basic qualities for any teacher. After active participation in scientific research activities, teachers can maintain enthusiastic attitude and put this enthusiasm into teaching activities and promote the reform of teaching quality. In the meantime, teachers' ability of modern teaching technique should also be strengthened so that teachers can keep pace with the times both physically and mentally. With the combination of skillful use of science and technology, it is bound to be of some help to the quality of teaching activities.

During the construction period of "The 11th Five-year Plan" higher education undergraduate course teaching quality and teaching reform engineering, education department established tasks and goals of specialized major construction aiming at Assignment Book of the Construction of Specialized Majors in Higher Education. In fact, various projects of "The 11th Five-year Plan" construction are closely related. Therefore, construction of specialized majors in universities also needs to be combined with quality engineering. Through construction of curriculums, faculty, training base and awards of good teachers, relative constructions can be conducted centering on the major so as to strengthen comprehensive ability of the major and add new elements for the specialized construction of the major.

Construction of the characteristic development of college specialties of local universities can refer to professional training plans, professional curriculum system, practical teaching base, professional management assessment and professional structural distribution, combine its own orientation, center on the existing characteristics of the major and choose characteristic development of one or several aspects. However, during the characteristic development of college specialties, universities need to recombine majors or add new majors, optimize the distribution of major structure and adjust major direction so that it can satisfy demands of market economy.

In teaching of English majors in universities, construction of English curriculum aims to cultivate students' solid language skills and comprehensive cultural qualities so that students can adapt to requirements of social economy. According to this cultivation requirement, curriculum for English major in universities must be established on professional basic skills and knowledge, cultivate students' ability of applying English and open up courses of professional 
English knowledge and relative professional knowledge, such as international finance, computer application and so on; then, it should broaden students' English knowledge scope according to the society's demands for talents, utilize cultural difference and improve students' comprehensive communicative ability in various industries.

In addition, the characteristic development of college specialties also includes construction of textbook characteristics, moral education characteristics and so on, which all have certain promotion role to the characteristic development of college specialties.

\section{Conclusion:}

The characteristic development of college specialties is the primary work for universities' teaching task. From some conscious perspective, the characteristic development of college specialties can be used to test whether the university has professional ability. Therefore, during the characteristic development of college specialties, universities must combine their own history and orientation and improve their school-running abilities of different characteristic development so that the major can hold absolute advantages in demands of economic market.

\section{Reference:}

[1]Wu Yi, Cui Dan. Countermeasures of English Majors Teaching Staff Construction in Private Higher Learning Institution and Characteristic Development [J]. Journal of Jilin Radio and TV University ,2013,(8).

[2] Ma Ruimin, Zhao Jifeng, Sun Hao, etc.. Problems of Characteristic Development of Undergraduate Majors in Local Universities[J]. Value Engineering,2013,32.

[3] Gao Dan; Characteristic Development of Local Universities in Higher Education Popularization Stage [J]; Heilongjiang Education (Higher Education Research and Evaluation);2008 (12)

[4] Zhang Xiangle; Problems about Local Universities Strengthening Undergraduates' Professional Skills [J]; Further Education Researches ;2005 (03)

[5] Han Yingli;; Explorations of Characteristic Development of Teaching Team in Local Universities [J];Gansu Science;2011 (03) 